\title{
Influence of motion activity on psycho emotional status of scoliotic patients treated with brace
}

\author{
Anatoliy Levitskiy", S Yaroslavska, D Chekryzhev, K Rychlevskiy, V Pliatsek, O Velikiy, O Bebeshko \\ From 7th International Conference on Conservative Management of Spinal Deformities \\ Montreal, Canada. 20-22 May 2010
}

\section{Introduction}

Treatment of spinal deformity can lead to psycho emotional disorders. One of the conducive factor is the motion activity decrease. The goal of our research is identification of the influence of our rehabilitation program on the dynamic of psycho emotional disorders.

\section{Material and methods}

We studied clinical outcomes of Cheneau's brace treatment of 147 scoliotic patients (age 10 to 18). Patients were subdivided in 2 groups. Group A was made up by 79 patients whose brace treatment was combined with considerable motion activity based on our program. Rehabilitation program included aerobics, dancing (in brace), swimming, doing special exercise (in brace and without) individually or with rehabilitation specialists. Group B - 76 patients whose brace treatment was not followed by high motion activity. Psychological, psychosomatic and psycho physiological symptoms as well as questionnaires outcomes have been analyzed. The observation term is 1 year.

\section{Results}

Psycho emotional disorders in the first month of brace treatment occurred in both groups: group A - 78,9\%; group $B-79,1 \%$. By the end of the first year of brace treatment symptoms of psycho emotional disorders disappeared in group A - 91,1\%, group B - 71,5\%.

\section{Discussion}

Study of psycho emotional disorders in scoliotic patients under brace treatment.

Published: 10 September 2010

\section{doi:10.1186/1748-7161-5-S1-065}

Cite this article as: Levitskiy et al:: Influence of motion activity on psycho emotional status of scoliotic patients treated with brace. Scoliosis 2010 5(Suppl 1):065
Submit your next manuscript to BioMed Central and take full advantage of:

- Convenient online submission

- Thorough peer review

- No space constraints or color figure charges

- Immediate publication on acceptance

- Inclusion in PubMed, CAS, Scopus and Google Scholar

- Research which is freely available for redistribution
C Biomed Central 